\title{
Long-run Stock Return and Operating Performance following Private Debt Placements
}

\author{
Sheng-Syan Chen ${ }^{\mathrm{a}}$ \\ Robin K. Chou ${ }^{\text {b,* }}$ \\ Miaw-Jane Chen ${ }^{\mathrm{c}}$
}

${ }^{a}$ Department of Finance, College of Management, National Taiwan University, Taiwan

${ }^{b}$ Department of Finance, School of Management, National Central University, Taiwan

${ }^{c}$ Department of Accounting, College of Management, Tamkang University, Taiwan

Address correspondence to Robin K. Chou, Department of Finance, School of Management, National Central University, 300 Jungda Road, Jhongli, Taoyuan, Taiwan. Tel: 886-3-4227151; fax: 886-3-4252961; e-mail: rchou@cc.ncu.edu.tw. 


\title{
Long-run Stock Price and Operating Performance following Private Debt Placements
}

\begin{abstract}
$\underline{\text { Abstract }}$
This study examines the long-run stock return and operating performance following private debt placements. Presumably, private debt investors are more sophisticated and can monitor the issuing firms more effectively. Prior research suggests that the equity and public debt issuers underperform various stock return benchmarks in the long run. It is also found that the long-run operating performances significantly deteriorate for equity and public debt offering firms. It is generally concluded that managers time the market when issuing equities and public debts. In contrast, we do not find any consistent patterns of long-run under- or over-performance in stock returns and operating measures following private debt placements. Due to tighter monitoring, the information asymmetry problems are mitigated for private debt placements.
\end{abstract}




\section{Long-run Stock Price and Operating Performance following Private Debt Placements}

\section{Introduction}

Corporations have long been interested in the relative merits of issuing corporate debt through a public offering or a private placement. Prior research has focused on returns in a short window surrounding the date of the announcement of a public offering or a private placement of debt. Dann and Mikkelson (1984), Eckbo (1986), and Mikkelson and Partch (1986) all find an insignificant negative reaction to the announcement of public straight debt offerings, but a significant negative effect to the announcement of public convertible debt offerings. Mikkelson and Partch (1986) and James (1987) document either a non-positive price effect, or a statistically significant negative stock price response to private debt placement. Field and Mais (1991) find a statistically significant positive stock price response to the announcement of private convertible debt placement.

Other than examining the short-run announcement returns, there have been many studies focused on the long-run performance following securities offerings. Long-run studies can provide additional evidence about the information content of security issues. Past research suggests that the equity issuers underperform various stock return benchmarks in the long run either using public offering or private placement (e.g., Spiess and Affleck-Graves, 1995; Loughran and Ritter, 1995, 1997; and Hertzel etc., 2002). It is 
suggested that managers time equity issues to take advantage of "window of opportunity" to issue overvalued equity.

Studies have also documented large post-issue declines in operating performance for straight- and convertible-debt issuing firms. Lee and Loughran (1998) and McLaughlin, Safieddine and Vasudevan (1998) implement the buy-and-hold abnormal return method to examine convertible debt offerings. They report that the buy-and-hold returns significantly under-performed their matched counterparts in the long-run by $-3.9 \%$ and $-11.4 \%$, suggesting that a firm tends to issue convertible debt when its stock is overvalued. Spiess and Affleck-Graves (1999) find a substantial long-run post-issue under-performance in smaller, younger and NASDAQ-listed firms that had made straight and convertible debt offerings. They attribute this to investor's underestimation of cash flow problems after the offering or to management's overoptimism about future prospects. Bae, Jeong, Sun, and Tang. (2002) show that convertible debt issuers experience a significant decline in operating performance from the pre- to post-issue period, but that straight debt issuers do not.

These studies empirically evaluate the long-run performance over an extended period following equity and debt offerings and most of them cast doubt on the efficient market concept. They show that the market price of the issuing firm does not fully reflect the information content of security offerings during the announcement period, due to significant long-run under- or over-performance. Various theoretical models have been proposed to 
explain the long-run abnormal performances. Daniel, Hirshleifer, and Subrahmanyam (1998), Barberis, Shleifer, and Vishny (1998) and Odean (1998) presented theoretical models based on the well-known psychological biases that are consistent with investors' under- or over-reaction to information events.

Most of the long-run studies on debt issuances have been limited to public debt offerings, except for Dichev and Piotroski (1999), who apply the balance approach (i.e., identify public vs. private debt issuances by examining the relative increases in corporate debentures account and long-term notes payable account) to indirectly identify private debt issuances. They find no abnormal returns for the five years following straight debt issues. They also find that public debt issuers and large convertible debt issuers tend to underperform the market, while private debt issuers tended to outperform the market. Nevertheless, the balance-sheet-based approach does not yield a clean classification of public or private debt offerings

Compared to public debt offerings, private debt placement has received less attention in the literature. Private debt placement is a significant source of funds for U. S. medium-sized companies. During 1994-1996, the gross issuance of private debt placements by non-financial corporations was almost $40 \%$ of that in the public market [e.g., Prowse (1997)]. At the end of 1996, the non-financial corporate sector had about $\$ 450$ billion of private debt placements outstanding, which is roughly $50 \%$ of the amount of public bonds 
(\$950billion) outstanding [e.g., Prowse (1997)]. The terms of private debt placements are generally different from those of public debt offerings. Private debt placements have smaller load size and shorter maturity than those of public bonds. Covenants are tighter and renegotiation is more likely for private debt than for public debt. The private debt placements are likely prevalent for firms, which are smaller, and operate in an environment that has higher degree of information asymmetries. These firms require tighter monitoring, a function for which private debt is going to better provide.

In this study, we search for the exact announcement dates of private placements and investigate the long-run stock return and operating performance following private straight-debt and convertible-debt placement. Our results will provide additional evidence for accessing investors' behavior during the time of private debt placements.

The remainder of the paper is organized as follows. Section 2 describes the sample selection process and the research method. Section 3 presents the results of the post-announcement stock price performance. Section 4 reports the results of the long-run operating performance. Finally, a conclusion is provided in section 5. 


\section{Data and Research methodology}

\subsection{Data and Sample Selection}

The initial sample of private straight and convertible debt offerings is collected from the Securities Data Company's (SDC) online databases for the period from January 1989 to December 2002. ${ }^{1}$ To be included, the company must have been listed on the Center for Research in Securities Prices (CRSP) monthly tape at the time of the offering and have a non-negative book-to-market ratio available on the COMPUSTAT files for the year-end prior to the debt offering. For a firm that made several announcements of the same type of security, we only the first announcement is included.

\section{[Insert Table 1 here]}

Table 1 summarizes the sample distribution by year, by type of financing, by industry group and by exchange. The number of offerings varies from year to year. Panel A indicates that in 1989 and 1990 there are relatively small numbers of convertible debt offerings, while there are more straight debt offerings in 1989. There are more convertible debt offerings during 2001 and 2002. Other than these years, convertible debt and straight debt placements are roughly evenly distributed across years. Panel B shows that our final sample consists of 1,074 private debt offerings, which include 899 private straight debt

\footnotetext{
1 This article focuses on the traditional market of private debt placement, which is distinct from the Rule 144A market of private debt placement.
} 
placements and 175 private convertible debt placements. Private straight debt placements are made by 429 industries and 550, 60, and 289 of these firms are listed on the NYSE, Amex and NASDAQ, respectively. Private convertible debt offerings are made by 115 industries, and 44, 16, and 115 of these firms are listed on the NYSE, Amex and NASDAQ, respectively.

In Panel C, we present the descriptive statistics for each type of offerings. The mean (median) issuing size is $\$ 79$ (\$36.2) million and \$58.89 (\$22.1) million for straight debt and convertible debt, respectively. The issuing amount for straight debt is larger than that for convertible debt. The mean (median) firm size, as measured by the market equity, is $\$ 2,339.11$ (\$425.95) million for the straight debt issuers and $\$ 857.86$ (\$137.32) million for the convertible debt issuers. Firms that made straight debt offerings are, on average, more than three times as large as those making convertible debt offerings. The mean (median) book to market ratio is $0.98(0.6)$ for the straight debt issuers and $0.79(0.42)$ for the convertible debt issuers. The book-to-market ratio of the straight debt firms is higher than that of the convertible debt firms. The average (median) firm age for straight debt firms, which is $5,416(5,301)$ days, is greater than the average (median) firm age for convertible debt firms, which is $3,055(2,119)$ days.

\subsection{Research Methodology}

Different methodologies may produce nontrivial differences in estimating the long-run abnormal returns [e.g., Mitchell and Stafford (1998)]. Many studies use some form 
of cumulative abnormal return to detect the long-run performance of debt offerings. However, Kothari and Warner (1997) and Barber and Lyon (1997) show that long-run cumulative abnormal returns can lead to biased test statistics. They favor the use of buy-and-hold abnormal returns, because they reflect compounded calculated long-run returns and can measure investor experience. Fama (1998) suggested the use of calendar abnormal returns, because they have better statistical properties and allow for cross-sectional dependence in sample observations. We provide evidence by both the buy-and-hold and the calendar abnormal returns. We describe our methodologies in detail below.

\subsubsection{Buy-and-hold Abnormal Return Method}

We first apply the methodology of Barber and Lyon (1997) to estimate the long-run buy-and-hold abnormal returns. The buy-and-hold abnormal return (BHAR) for stock $i$ over the period from time $t$ to time $T$ is defined as:

$$
\begin{aligned}
& B H R_{i, t: T}=\prod_{t}^{T}\left(1+R_{i t}\right) \\
& B H R_{c t r l, t: T}=\prod_{t}^{T}\left(1+R_{c t r l, t}\right) \\
& B H A R_{i, t: T}=B H R_{i, t: T}-B H R_{c t r l, t: T}
\end{aligned}
$$

where $B H R_{i, t: T}$ is the buy-and-hold return of the sample firm and $B H R_{c t r l t: T}$ is the buy-and-hold return of the control firm over the same period. Barber and Lyon (1997) conclude that the matched control firm approach leads to unbiased test statistics. The procedure for identifying control firms is similar to that used by Hertzel, Lemmon, Linck and 
Rees (2002). First, we exclude all CRSP firms that previously issued private debt and select a single control firm within the same exchange group for each sample firm as of the year-end prior to the private placement. Firms are matched based on three benchmarks: (1) firm size (market value of common equity); (2) the industry (based on the four-digit SIC code) and firm size; (3) the book-to-market and firm size.

The computation of the buy-and-hold abnormal returns begins in the month after the private debt announcement and continues through one-year, three-year and five-year periods following the announcement or until either the sample or the control firm is de-listed, whichever is sooner. We truncate the sample due to the conclusions of Barber and Lyon (1997) that long-run results are generally robust to truncating or filling in the missing returns after de-listing. After $B H A R_{i, t: T}$ is obtained for each of the $n$ firms in the sample, the equally-weighted and value-weighted cross-sectional average buy-and-hold abnormal return $\left(\overline{B H A R}_{t: T}\right)$ are calculated as follows:

$$
\overline{\operatorname{BHAR}}_{t: T}=\sum_{i=1}^{n} w_{i} \cdot \mathrm{BHAR}_{i, t: T}
$$

where $w_{i}=1 / n$ for the equally-weighted returns and $w_{i}$ is the market value of stock $i$ divided by the total market value of all the samples for the value-weighted returns. To assess the statistical significance, we employ the conventional $t$-statistic.

However, the distribution of the buy-and-hold abnormal returns still has a positive skewness problem even under the control firm approach [e.g., Kothari and Warner (1997); 
Barber and Lyon (1997); and Barber, Lyon and Tsai (1999)]. For statistical testing, we combine the control firm approach with a bootstrapping procedure used by Hertzel, et al. (2002). Specifically, we compute the one-, three-, and five-year buy-and-hold returns for each sample firm beginning the month after the announcement of private debt placement and take the cross-sectional average. We then form a pseudo-portfolio by randomly selecting with replacement a control firm that has the same matching characteristics in the size decile, the industry and size decile, and the book-to-market and size decile as the sample firm, respectively, at the year-end prior to the private debt placement announcement.

This matching process continues until each sample firm is represented in this pseudo-portfolio. After forming the pseudo-portfolio, we estimate the one-, three-, and five-year buy-and-hold returns for each control firm by the same approach for the sample firm. This yields one observation of the cross-sectional average of the matching firm buy-and-hold returns, $\overline{B H R}_{p, t: T}$. These steps are repeated 1,000 times to obtain 1,000 pseudo-portfolio mean observations. This provides us an empirical distribution of $\overline{B H R}_{p, t: T}$. The $p$-value of the sample is calculated as the fraction of the 1,000 pseudo-portfolio mean $\overline{B H R}_{p, t: T}$ that is larger in magnitude than the mean sample firm return, $\overline{B H R}_{t: T}$.

\subsubsection{Calendar Time Abnormal Return Model}

The calendar time abnormal return method was first used by Jaffe (1974) and Mandelker (1974) and strongly advocated by Fama (1998). Under the procedure of the 
calendar time abnormal return method, the cross-sectional correlation of the sample firm's returns can be automatically accounted. We use two variations of the calendar-time portfolio method to measure the long-run performance following private debt placement: the Fama and French (1993) three-factor model and the Carhart (1997) four-factor model.

For each calendar month in our sample period, we form portfolios of sample firms that have announced private straight-debt or convertible-debt placements in the previous one-, three- and five-year periods and calculate the monthly returns for both the equally- and value-weighted portfolios. In order to avoid statistical problems caused by overlapping returns, no firms are included more than once in the portfolio during any given five-year window. We then apply the Fama and French (1993) three-factor model as follows:

$$
R_{p t}-R_{f t}=\alpha_{p}+\beta_{m}\left(R_{m t}-R_{f t}\right)+\beta_{s} S M B_{t}+B_{h} H M L_{t}+\varepsilon_{t}
$$

where $R_{p t}$ is the portfolio return of sample firms in month $t$ (either equally-weighted or value-weighted), $R_{f t}$ is the one-month Treasury Bill rate, $\left(R_{m t}-R_{f t}\right)$ is the excess return on the market portfolio, $S M B_{t}$ is the difference of the returns between the value-weighted portfolios of small stocks and big stocks, and $H M L_{t}$ is the difference of the returns between the value-weighted portfolios of high book-to-market stocks and low book-to-market stocks.

In model (3), $\alpha_{p}$ measures the mean monthly abnormal return, which is zero under the null hypothesis of no long-run abnormal returns. A portfolio may contain from 1 to 50 firms in any given calendar month, therefore, we use both the ordinary least squares (OLS) 
and the weighted least squares (WLS) procedures to estimate $\alpha_{p}$. The WLS model is used to reveal any event bunching effect that may occur with selective management events [e.g., Loughran and Ritter (2000)]. Monthly returns in the WLS model are weighted by the square root of the number of sample firms contained in the monthly portfolio. However, as shown by Fama and French (1993, 1998), Lyon et al. (1999), Lee and Swaminathan (2000), Mitchell and Stafford (2000), and Boehme and Sorescu (2002), the three-factor model cannot completely explain the cross-sectional variations due to the momentum factors. Thus, it is important to control for the momentum effect. We utilize the Carhart (1997) four-factor model, which includes a price momentum factor, to control the momentum biases.

The Carhart four-factor model encompasses the Fama and French (1993) three factors plus an additional factor to capture the one-year momentum effects. The model is presented as follows:

$$
R_{p t}-R_{f t}=\alpha_{p}+\beta_{m}\left(R_{m t}-R_{f t}\right)+\beta_{s} S M B_{t}+B_{h} H M L_{t}+\beta_{r} P R 1 Y R_{t}+\varepsilon_{t}
$$

All the terms are similarly defined as those in equation (3) and $P R 1 Y R_{t}$ is the price momentum factor as defined in Carhart (1997), which is the difference between an equally-weighted portfolio return of stocks with the highest 30 percent returns and an equally-weighted portfolio return of stocks with the lowest 30 percent returns in months $t-12$ to $t$-2 The portfolios include all NYSE, Amex, and Nasdaq stocks. 


\section{Post Announcement Long-run Abnormal Returns}

\subsection{Buy-and-Hold Abnormal Returns}

\subsubsection{Straight debt}

We begin our empirical analysis by presenting the buy-and-hold abnormal return. Table 2 presents the one-, three-, and five-year raw returns of the straight debt sample firms from 1989 to 2002, and the buy-and-hold abnormal returns, as measured by the three control firm benchmarks: size, size-SIC and size-BE/ME. As shown in Table 2, the mean (median) one-, three- and five-year equally- or value-weighted buy-and-hold raw returns are all significantly positive. In addition, for all the equally-weighted long-run BHARs, the one-, three, and five-year periods are all insignificant, regardless of the horizon and benchmark. The results show no evidence of long-run abnormal returns.

\section{[Insert Table 2 here]}

Compared to the insignificant equally-weighted BHARs results, the value-weighted BHAR, 0.0543, for the one-year size-BE/ME matched portfolio is significant at the $1 \%$ level. Compared to the one-year horizon results, the mean five-year BHARs for the size-matched and the mean three- and five-year BHARs for size-BE/ME-matched portfolios are $-0.2074,-0.0882$ and -0.1698 , respectively and are significant at the $1 \%$ level. Usually, there are more significant results for value-weighted BHARs. However, different results are obtained by different benchmarks. The inconsistent patterns of the equally- and 
value-weighted BHARs do not support the existence of long-run abnormal returns after private straight-debt placements.

\subsubsection{Convertible debt}

Table 3 presents the results for the one-, three-, and five-year raw returns of convertible debt sample firms, and the buy-and-hold abnormal returns. Table 3 shows that most of the equally-weighted BHARs, following private convertible-debt placements, are negative regardless of the horizon and the benchmark, although most are statistically insignificant, except for the BHARs of the one- and three-year size-matched portfolios.

\section{[Insert Table 3 here]}

The value-weighted mean one-year BHARs are all significantly negative, regardless of the benchmark. As the return horizon is increased, the value-weighted become mostly insignificant. The results indicate that it may be difficult for investors to earn abnormal return profits by trading on this under-performance. In addition, Hertzel et al. (2002) show that public firms that placed equity privately would experience negative post-announcement stock price performance. The above results seem to reflect the equity features of the convertible debt.

Furthermore, the results in Table 2 and Table 3 support Mitchell and Stafford's (2000) argument that BHARs tend to magnify spurious abnormal returns caused by mis-specified asset pricing models over long horizons. For example, both equally- and value-weighted 
five-year BHARs are larger in magnitude than the corresponding three-year BHARs. We do not find consistent patters of long-term abnormal returns, although convertible debt issuers seem to perform worse, due to its equally features.

\subsection{Calendar-time Abnormal Returns}

\subsubsection{Fama and French Three-factor Model}

Table 4 and Table 5 report the results of the one-, three- and five-year calendar time abnormal returns (CTARs) for the sample of private straight debt and convertible debt placements using the Fama and French three-factor model.

\subsubsection{Straight debt}

The equally-weighted one-, three- and five-year periods CTARs for the OLS and WLS models are all negative but insignificant. For the value-weighted CTARs, none of them are significant. Table 4 does not show evidence of long-run abnormal returns following private straight placements. Combining the results in Table 2 and those in Table 4, we do not see consistent patterns of long-run abnormal returns by either BHARs or CTARs. In addition, from Table 4 the CTARs by the OLS model and the WLS model are similar, which does not support the event-bunching hypothesis of Loughran and Ritter (2000).

\section{[Insert Table 4 here]}

\subsubsection{Convertible debt}

From Table 5, by WLS, the CTARs following private convertible debt placements are $-1.1509,-0.9992$ and -0.6696 for the one-, three- and five-year equally-weighted 
portfolio, and are significant. The other equally- or value-weighted CTARs for the one-, three- and five-year periods are all statistically insignificant, but are mostly negative, for both the OLS and the WLS models. These results support the equity-like features as a cause of underperformances for the convertible debt security, similar to the results found by the BHAR method. Overall, we do not find consistent patterns of significant abnormal returns following private convertible debt placements.

\section{[Insert Table 5 here]}

\subsubsection{Carhart Four-factor Model}

\subsubsection{Straight debt}

From Panel B of Table 6 shows that the only significant CTARs are from the three-year equally-weighted portfolios are -0.2779 by OLS and -0.2840 by WLS. The other CTARs are all insignificant. Again, we do not find consistent patterns of long-run abnormal returns following private straight debt placements, even when the momentum factor is controlled. Our results do not support the event-bunching hypothesis of Loughran and Ritter (2000), since the results by the OLS and WLS methods are similar.

\section{[Insert Table 6 here]}

\subsubsection{Convertible debt}

From Table 7, the only significant CTARs from the WLS equally-weighted three-year abnormal return, which is -0.8814 , and significant at the $10 \%$ level. There is no consistent evidence supporting the existence of the long-run abnormal returns following private convertible debt placement, even when the momentum factor is controlled. 


\section{[Insert Table 7 here]}

\subsection{Long-run Abnormal Returns by Firm and Offering Characteristics}

All results in the preceding analyses do not support the existence of long-run abnormal returns following private straight and convertible debt placements. Spiess and Affleck-Graves (1999) show that under-performance following straight or convertible debt issues is more severe for smaller, younger, and NASDAQ-listed firms. To further examine whether the results are sensitive to some firm and market specific characteristics, we partition our sample into quartiles based on the firm size, book-to-market ratio, firm age, issue size, and bond rating, as well as three major exchanges. The quartile returns are calculated by using the BHAR method.

The results generally show that the patterns of long-term abnormal returns are unstable. $^{2}$ That is, even after partitioning our samples according to various firm- and market-specific characteristics, we still do not find significant under- or over-performance following private placements of debt.

\section{Operating Performance}

McLaughlin, Safieddine and Vasudevan (1998) have documented a small improvement in operating performance before a public convertible debt offering and a

\footnotetext{
2 The results are qualitatively similar to those for the whole samples. They are omitted and available upon
} request. 
significant decline in operating performance in the post-issue period. We turn our attention to whether private debt placement will cause any changes in the long-run operating performance.

We examine the operating performance of our sample firms over a seven-year period around the private debt placement offer date and report the unadjusted and industry-adjusted year-by-year changes in operating performance, and the unadjusted and industry-adjusted changes in operating performance from year -1. Following Lee and Loughran (1998), Dichev and Piotroski (2001) and Hertzel et al. (2002), to measure the operating performance, we compute the following ratios: (1) The profit margin (IBER/sales) which is a ratio of net income before extraordinary items (Compustat item \#18) to sales (Compustat item \#12).

The IBER/assets represents the ratio of net income before extraordinary items divided by the total assets (Compustat item \#6). (3) The return on equity (IBER/equity) is the ratio of net income before extraordinary items to the book value of the equity (Compustat item \#60). We also calculate (4) the $\mathrm{CE}+\mathrm{RD} /$ assets which is the ratio of capital expenditures (Compustat item \#128) plus R\&D expenditures (Compustat item \#46) divided by total assets, and (5) the $\mathrm{M} / \mathrm{B}$ which is the ratio of the market value to the book value of the equity. Finally, in order to estimate a company's creditworthiness, we calculate (6) TIE (times-interest-earned ratio), which is a measure of operating income before interest expenses and taxes over interest expenses. We use median values because the operating performance measures can be 
skewed, and the mean value is particularly sensitive to outliers. We calculate the industry-adjusted performance measures in order to control the industry effects.

\subsection{Results of Operating Performance}

\subsubsection{Straight debt}

Panel A of Table 8 shows the levels of the sample firm's performance measures and the industry-adjusted performance measures. Panel B of Table 8 shows the sample firm's and the industry-adjusted year-by-year changes, while Panel $\mathrm{C}$ of Table 8 reports the sample firm's and the industry-adjusted changes from year -1 . The median industry-adjusted performance relative to the median firm in the same four-digit SIC industry shows that the private straight debt placement issuer performs significantly better than its industry counterpart throughout the pre- and post-offer periods. It is worth noting that the offering firm has a higher $\mathrm{CE}+\mathrm{RD} /$ assets ratio, which indicates that the offering firm has more capital expenditures and research and development expenses than its industry counterparts do. In addition, we also find that the M/B ratio is significantly higher for the issuers than for the industry median firms.

In Panels $\mathrm{B}$ and $\mathrm{C}$, we see that most of the industry-adjusted median change in performance decline significantly from year -1 to years $0,1,2$ and 3 . These results are not consistent with the theory that management times their security issue to periods of relatively high operating performance. A possible reason is that private placement can reduce the 
information asymmetry through the negotiation process between the issuing firms and the debt investors. Thus, the management is not likely to window dress the financial data before the issue, because sophisticated or institutional investors have better judgment and can obtain better information. We also find that the empirical evidence shown by the TIE ratios in Panel A of Table 8 is all significantly higher for the issuers than the industry median. This supports the assumption that private creditors are more concerned about receiving the interest payments and the principle on time.

\section{[Insert Table 8 here]}

\subsubsection{Convertible debt}

The levels of median and industry-adjusted median operating performance for convertible debt issuers are shown in Panel A of Table 9. The industry-adjusted median performance for each measure gives different results. The results show the private convertible debt issuers generally perform worse than its industry counterparts in the pre-announcement period. The $\mathrm{CE}+\mathrm{RD} /$ assets and $\mathrm{M} / \mathrm{B}$ ratios of sample firms are generally higher than those of the industry medians.

Panel B shows that the industry-adjusted year-by-year median changes for performance measures are usually not significant, except for the median change of IBER/assets in year $(-2,-1)$ and of IBER/equity in years $(-3,-2)$ and $(-2,-1)$. Panel C shows no evidence for median changes in IBER/sales, IBER/assets or IBER/equity from year -1 . Therefore, the evidence suggests that firms do not experience any significant changes in operating performance prior to and after the offering of private convertible debt. 


\section{[Insert Table 9 here]}

The operating performance results do not show consistent patterns of changes, either before or after private convertible debt placements. This is likely because private debt investors are more sophisticated and due to tighter monitoring, the operating performance does not deteriorate as has been found in the equity offering literature.

\section{Conclusions}

We examine the long-run stock return and operating performance for sample firms issuing straight and convertible debt through private placements from 1989 to 2002 . We find that firms offering private straight debt placements do not show consistent evidence of long-run abnormal returns by the buy-and-hold abnormal return method, the Fama and French three-factor model, and the Carhart four-factor model. By directly identifying the announcement dates of private debt offerings, our results are inconsistent with the evidence in Dichev and Piotroski (1999), who show that private debt issuers outperform the market.

For convertible debt, due to its equity-like features, it is reasonable to expect that private convertible debt placement will lead to the same long-run stock price underperformance as found by Hertzel et al. (2002) and Dichev and Piotroski (1999). Nevertheless, we do not find any systematic evidence showing the existence of long-run abnormal returns following private convertible debt placement. 
We also investigate the long-run operating performance of private debt placement. The results show that private straight debt placement issuer performs significantly better than its industry counterpart does throughout the pre- and post-offer periods, for all the performance measures. We do not find evidence showing that firms time their security issues during periods of relatively high operating performance and that the performance levels decline after issuing. A possible reason is that private debt placement can reduce information asymmetry through the negotiation process between the issuing firm and the investors. In other words, management is not likely to window dress the financial data before the issue.

For convertible debt, we find that the private convertible debt issuer performs significantly worse than its industry counterpart in the pre-placement period. Overall, our empirical results suggest that firms do not experience any long-run abnormal returns, nor any significant changes in operating performance prior to and after the offering of private convertible debt. 


\section{References}

Bae, G. S., J. Jeong, H. L. Sun and A. P. Tang, 2002, Stock returns and operating performance of securities issuers, Journal of Financial Research 25, 337-352.

Barber, B. M. and J. D. Lyon, 1997, Detecting long-run abnormal stock returns: The empirical power and specification of test statistics, Journal of Financial Economics 43, 341-372.

Barberis, N., A. Shleifer and R. Vishny, 1998, A model of investor sentiment, Journal of Financial Economics 49, 307-343.

Boehme, R. D. and S. M. Sorescu, 2002, The long-run performance following dividend initiations and resumptions: Underreaction or product of chance? Journal of Finance 57, 871-900.

Carhart, M. M., 1997, On persistence in mutual fund performance, Journal of Finance, 52, $57-82$.

Cheng, L., 1995, Equity issue underperformance and the timing of security issues, Working paper, MIT, Cambridge.

Daniel, K., D. Hirshleifer and A. Subrahmanyam, 1998, Investor psychology and security market under- and overreactions, Journal of Finance 53, 1839-1885.

Dann, L. Y. and W. H. Mikkelson, 1984, Convertible debt issuance, capital structure change and financing-related information, Journal of Financial Economics 13, 157-186.

Dichev, I. D. and J. D. Piotroski, 1999, The performance of long-run stock returns following issues of public and private debt, Journal of Business Finance and Accounting 26, 1103-1132.

Dichev, I. D. and J. D. Piotroski, 2001, The long-run stock returns following bond ratings changes, Journal of Finance 56, 173-203.

Eckbo B. E., 1986, Valuation effects of corporate debt offerings, Journal of Financial Economics 15, 119-151.

Fama, E. F. and K. R. French, 1993, Common risk factors in the returns on stocks and bonds, Journal of Financial Economics 49, 283-306.

Fama, E. F., K. R. French, D. G. Booth and R. Sinquefield, 1993, Difference in the risks and returns of NYSE and NASD stocks, Financial Analysts Journal 49, 37-41.

Fama, E. F., 1998, Market efficiency, long-term returns, and behavioral finance, Journal of Financial Economics 33, 3-56. 
Fields L. P. and E. L. Mais, 1991, The valuation effects of private placements of convertible debt, Journal of Finance 46, 1925-1932.

Hertzel, M., M. Lemmon, J. S. Linck and L. Rees, 2001, Long-run performance following private placements of equity, Working paper, Arizona State University.

Jaffe, J. F., 1974, Special information and insider trading, Journal of Business 47, 410-428.

James, C., 1987, Some evidence on the uniqueness of bank loans, Journal of Financial Economics 19, 217-235.

Jewell, J. and M. Livingstion, 1997, The long-run performance of firms issuing bonds, Journal of Fixed Income 7, 61-66.

Jung, K., Y. C. Kim and R. M. Stulz, 1996, Timing, investment opportunities, managerial discretion, and the security issue decision, Journal of Financial Economics 42, 159-185.

Lee, I. and T. Loughran, 1998, Performance following convertible bond issuance, Journal of Corporate Finance 4, 185-207.

Loughran, T., 1993, Market microstructure or the poor performance of initial public offerings? Journal of Financial Economics 33, 241-260.

Loughran, T. and J. R. Ritter, 2000, Uniformly least powerful tests of market efficiency, Journal of Financial Economics 55, 361-389.

Lyon, J. D., B. M. Barber and C. Tsai, 1999, Improved methods for tests of long-run abnormal stock returns, Journal of Finance 56, 165-201.

Kothari, S. P. and J. B. Warner, 1997, Measuring long-horizon security price performance, Journal of Financial Economics 43, 301-339.

Mandelker, G., 1974, Risk and return: the case of merging firms, Journal of Financial Economics 1, 303-336.

McLaughlin, R., A. Safieddine and G. K. Vasudevan, 1998, The long-run performance of convertible debt issuers, Journal of Financial Research 21, 373-388.

Mikkelson, W. H. and M. M. Partch, 1986, Valuation effects of security offerings and issuance process, Journal of Financial Economics 15, 31-60.

Mitchell, M. L. and E. Stafford, 2000, Managerial decisions and long-term stock price performance, Journal of Business 73, 287-329.

Odean, T., 1998, Are investors reluctant to realize their losses? Journal of Finance 53, 1775-1798. 
Prowse, S. D., 1997, The economics of private placements: middle-market corporate finance, life insurance companies, and a credit crunch, Economic Review 3, 12-24.

Spiess, D. K. and J. Affleck-Graves, 1999, The long-run performance of stock returns following debt offerings, Journal of Financial Economics 54, 45-73.

Szewczyk, S. H. and R. Varma, 1991, Raising capital with private placements of debt, Journal of Financial Research 14, 1-13. 


\section{Table 1 Sample Distribution of Private Placements of Debt}

This table presents the frequency distribution of the sample by year, type of financing, exchange and the number of different industry groups in which the offering firms operate. The full sample consists of 1074 private placements of convertible and straight debt offered, which was reported from the Securities Data Company's (SDC) online databases over the period from January 1989 through December 2002. To be included, the company must be listed on the Center for Research in Securities Prices (CRSP) monthly tape at the time of the offering and has a non-negative book-to-market ratio available on COMPUSTAT files for the year-end prior to the debt offering. For firm made several announcements of the same type of security, only the first announcement is included.

\begin{tabular}{|c|c|c|c|c|c|c|}
\hline \multicolumn{7}{|c|}{ Panel A: Frequency Distribution of Private Debt Placement Announcements by Year } \\
\hline & \multicolumn{2}{|c|}{ Number of announcements } & \multicolumn{2}{|c|}{ Percentage of sample } & \multicolumn{2}{|c|}{$\begin{array}{c}\text { Cumulative percentage of } \\
\text { sample }\end{array}$} \\
\hline Year & $\begin{array}{c}\text { Convertible } \\
\text { debt }\end{array}$ & Straight debt & $\begin{array}{c}\text { Convertible } \\
\text { debt }(\%)\end{array}$ & $\begin{array}{c}\text { Straight debt } \\
(\%)\end{array}$ & $\begin{array}{c}\text { Convertible } \\
\text { debt }(\%)\end{array}$ & $\begin{array}{c}\text { Straight debt } \\
(\%)\end{array}$ \\
\hline 1989 & 3 & 182 & 1.71 & 20.24 & 1.71 & 20.24 \\
\hline 1990 & 1 & 99 & 0.57 & 11.01 & 2.29 & 31.26 \\
\hline 1991 & 14 & 89 & 8.00 & 9.90 & 10.29 & 41.16 \\
\hline 1992 & 12 & 49 & 6.86 & 5.45 & 17.14 & 46.61 \\
\hline 1993 & 8 & 73 & 4.57 & 8.12 & 21.71 & 54.73 \\
\hline 1994 & 11 & 62 & 6.29 & 6.90 & 28.00 & 61.62 \\
\hline 1995 & 9 & 67 & 5.14 & 7.45 & 33.14 & 69.08 \\
\hline 1996 & 14 & 39 & 8.00 & 4.34 & 41.14 & 73.41 \\
\hline 1997 & 10 & 55 & 5.71 & 6.12 & 46.86 & 79.53 \\
\hline 1998 & 8 & 50 & 4.57 & 5.56 & 51.43 & 85.09 \\
\hline 1999 & 7 & 45 & 4.00 & 5.01 & 55.43 & 90.10 \\
\hline 2000 & 7 & 31 & 4.00 & 3.45 & 59.43 & 93.55 \\
\hline 2001 & 33 & 33 & 18.86 & 3.67 & 78.29 & 97.22 \\
\hline 2002 & 38 & 25 & 21.71 & 2.78 & 100.00 & 100.00 \\
\hline Total & 175 & 899 & 100.00 & 100.00 & & \\
\hline
\end{tabular}

Panel B: Frequency Distribution of Private Debt Placement Announcements by Type of Financing, Type of Exchange, and Number of Different Industrial Groups

\begin{tabular}{lccccc}
\hline Type of Financing & Number of Private & Number of Different & \multicolumn{3}{c}{ Exchange } \\
\cline { 4 - 6 } & Placements & Industry Groups & NYSE & Amex & NASDAQ \\
\hline Convertible debt & 175 & 115 & 44 & 16 & 115 \\
Straight debt & 899 & 429 & 550 & 60 & 289 \\
\hline Total Sample & 1074 & & 594 & 76 & 404 \\
\hline
\end{tabular}

Panel C: Sample Characteristics of Private Debt Placement

\begin{tabular}{|c|c|c|c|c|c|c|}
\hline & \multicolumn{3}{|c|}{ Straight debt } & \multicolumn{3}{|c|}{ Convertible debt } \\
\hline & $\mathrm{N}$ & Mean & Median & $\mathrm{N}$ & Mean & Median \\
\hline Issue size (millions) & 899 & 79.00 & 36.20 & 175 & 58.89 & 22.10 \\
\hline Market value of equity (millions) & 899 & 2339.11 & 425.95 & 175 & 857.86 & 137.32 \\
\hline Book-to-market & 899 & 0.98 & 0.60 & 175 & 0.79 & 0.42 \\
\hline Relative issue size (\%) & 899 & 0.29 & 0.10 & 175 & 0.40 & 0.15 \\
\hline Firm age (trading days) & 899 & 5416.00 & 5301.00 & 175 & 3055.00 & 2119.00 \\
\hline
\end{tabular}


Table 2 Long-run Buy-and-Hold Abnormal Returns for Firms offering the Private Placement of Straight Debt

This table presents the raw, one-, three- and five-year long-run buy-and-hold abnormal returns of sample firms following an offering of the private straight debt placement and their long-run buy-and-hold adjusted abnormal returns relative to their control firms under different characteristics. All the sample firms are reported from the Securities Data Company's (SDC) online databases over the period from January 1989 through December 2002. The control firms are firms that match on the basis of size, size and industry, and size and book to market equity ratio. A buy-and-hold abnormal return (BHAR) is the difference between the buy-and-hold return of the sample firm and that of the control firm. The conventional t-statistics are reported. The p-values are based on bootstrap procedures and represent the percentile ranking of the announcing firms mean return relative to 1,000 mean returns from randomly selected matched portfolios.

\begin{tabular}{|c|c|c|c|c|c|c|c|c|}
\hline & \multirow{2}{*}{\multicolumn{2}{|c|}{$\begin{array}{c}\text { Raw Returns } \\
\text { Private } \\
\text { Placement } \\
\end{array}$}} & \multicolumn{6}{|c|}{ Buy-and-hold Adjusted Returns (BHAR) in Percent } \\
\hline & & & \multicolumn{2}{|c|}{$\begin{array}{c}\text { Size } \\
\text { Matched } \\
\end{array}$} & \multicolumn{2}{|c|}{$\begin{array}{l}\text { Size/Industry } \\
\text { Matched }\end{array}$} & \multicolumn{2}{|c|}{$\begin{array}{l}\text { Size/BM } \\
\text { Matched } \\
\end{array}$} \\
\hline & EW & VW & EW & VW & EW & VW & EW & VW \\
\hline \multicolumn{9}{|c|}{ Panel A: One-year Buy-and-hold Abnormal Returns (\%) } \\
\hline $\mathrm{N}$ & 832 & 832 & 786 & 786 & 782 & 782 & 793 & 793 \\
\hline Mean & 0.0986 & 0.0845 & 0.0004 & 0.0201 & -0.0096 & -0.0071 & -0.0055 & 0.0543 \\
\hline Median & 0.0515 & 0.0364 & 0.0013 & -0.0194 & -0.0175 & -0.0107 & -0.0129 & 0.0279 \\
\hline t-statistic & $6.14 * * *$ & $7.54 * * *$ & 0.02 & 1.41 & -0.47 & -0.49 & -0.26 & $3.52 * * *$ \\
\hline Bootstrapped p-value & & & 0.64 & 0.12 & 0.39 & 0.47 & 0.50 & $<0.01$ \\
\hline \multicolumn{9}{|c|}{ Panel B: Three-year Buy-and-hold Abnormal Returns (\%) } \\
\hline $\mathrm{N}$ & 691 & 691 & 595 & 595 & 601 & 601 & 605 & 605 \\
\hline Mean & 0.4374 & 0.4609 & -0.0576 & -0.0394 & -0.0607 & -0.0401 & -0.0122 & -0.0882 \\
\hline Median & 0.2639 & 0.3882 & 0.0037 & -0.1485 & -0.0223 & -0.0228 & -0.0376 & -0.2093 \\
\hline t-statistic & $11.98 * * *$ & $16.81 * * *$ & -0.03 & -1.22 & -1.07 & -1.13 & -0.22 & $-2.65 * * *$ \\
\hline Bootstrapped p-value & & & 0.65 & 0.17 & 0.21 & 0.32 & 0.65 & $<0.01$ \\
\hline \multicolumn{9}{|c|}{ Panel C: Five-year Buy-and-hold Abnormal Returns (\%) } \\
\hline $\mathrm{N}$ & 547 & 547 & 430 & 430 & 433 & 433 & 455 & 455 \\
\hline Mean & 0.8970 & 1.0583 & -0.1060 & -0.2074 & 0.0044 & 0.0043 & 0.0937 & -0.1698 \\
\hline Median & 0.5496 & 0.7774 & -0.0013 & -0.0806 & 0.0426 & 0.1520 & 0.0812 & -0.0702 \\
\hline t-statistic & $13.27 * * *$ & $21.22 * * *$ & -1.02 & $-3.04 * * *$ & 0.97 & 0.05 & 0.94 & $-2.43 * *$ \\
\hline Bootstrapped p-value & & & 0.62 & $<0.01$ & 0.83 & 0.86 & 0.20 & $<0.01$ \\
\hline
\end{tabular}


Table 3 Long-run Buy-and-Hold Abnormal Returns for Firms Offering the Private Placement of Convertible Debt

This table presents the raw, one-, three- and five-year long-run buy-and-hold abnormal returns to sample firms following an offering of the private convertible debt placement and their long-run buy-and-hold adjusted abnormal returns relative to their control firms under different characteristics. All the sample firms were reported from the Securities Data Company's (SDC) online databases over the period from January 1989 through December 2002. The control firms are firms that match on the basis of size, size and industry, and size and book to market equity ratio. A buy-and-hold abnormal return (BHAR) is the difference between the buy-and-hold return of the sample firm and that of the control firm. The conventional t-statistics are reported. The p-values are based on bootstrap procedures and represent the percentile ranking of the announcing firms mean return relative to 1,000 mean returns from randomly selected matched portfolios.

\begin{tabular}{|c|c|c|c|c|c|c|c|c|}
\hline & \multirow{2}{*}{\multicolumn{2}{|c|}{$\begin{array}{c}\text { Raw Returns } \\
\text { Private } \\
\text { Placement }\end{array}$}} & \multicolumn{6}{|c|}{ Buy-and-hold Adjusted Returns (BHAR) in Percent } \\
\hline & & & \multicolumn{2}{|c|}{$\begin{array}{c}\text { Size } \\
\text { Matched }\end{array}$} & \multicolumn{2}{|c|}{$\begin{array}{l}\text { Size/Industry } \\
\text { Matched }\end{array}$} & \multicolumn{2}{|c|}{$\begin{array}{l}\text { Size/BM } \\
\text { Matched }\end{array}$} \\
\hline & EW & VW & EW & VW & EW & VW & EW & VW \\
\hline \multicolumn{9}{|c|}{ Panel A: One-year Buy-and-hold Abnormal Returns (\%) } \\
\hline $\mathrm{N}$ & 124 & 124 & 110 & 110 & 114 & 114 & 115 & 115 \\
\hline Mean & 0.0047 & -0.1739 & -0.1920 & -0.1878 & -0.0333 & -0.1144 & -0.0109 & -0.1249 \\
\hline Median & -0.1589 & -0.1669 & -0.1267 & -0.2734 & -0.0387 & -0.0409 & -0.1625 & -0.2282 \\
\hline t-statistic & 0.07 & $-4.32 * * *$ & $-2.12 * *$ & $-3.32 * * *$ & -0.40 & $-2.22 * *$ & -0.10 & $-2.54 * *$ \\
\hline Bootstrapped p-value & & & 0.03 & $<0.01$ & $0 . .54$ & $<0.01$ & 0.48 & 0.04 \\
\hline \multicolumn{9}{|c|}{ Panel B: Three-year Buy-and-hold Abnormal Returns (\%) } \\
\hline $\mathrm{N}$ & 69 & 69 & 55 & 55 & 50 & 50 & 56 & 56 \\
\hline Mean & 0.1857 & 0.1830 & -0.3219 & -0.5928 & -0.7229 & -1.1939 & -0.2719 & -0.0861 \\
\hline Median & 0.0250 & 0.2695 & -1.4289 & -0.4289 & -0.0152 & 0.0092 & -0.0185 & -0.0172 \\
\hline t-statistic & 1.53 & $1.66^{*}$ & $-1.68 *$ & $-2.89 * * *$ & -1.24 & -1.44 & -1.08 & -0.61 \\
\hline Bootstrapped p-value & & & 0.06 & $<0.01$ & 0.48 & 0.12 & 0.41 & 0.45 \\
\hline \multicolumn{9}{|c|}{ Panel C: Five-year Buy-and-hold Abnormal Returns (\%) } \\
\hline $\mathrm{N}$ & 51 & 51 & 37 & 37 & 38 & 38 & 39 & 39 \\
\hline Mean & 1.0261 & 1.0400 & -0.2544 & -0.1912 & -0.2926 & 0.3024 & -0.5476 & -1.6718 \\
\hline Median & 0.6950 & 0.6950 & -0.2721 & -0.8161 & 0.1994 & -0.0131 & -0.2038 & -0.2754 \\
\hline t-statistic & $3.62 * * *$ & $3.73 * * *$ & -0.60 & -0.47 & -0.47 & 0.73 & -0.95 & $-1.99 *$ \\
\hline Bootstrapped p-value & & & 0.85 & 0.64 & 0.69 & 0.25 & 0.48 & 0.07 \\
\hline
\end{tabular}




\section{Table 4 Long-run Abnormal Returns Following Private Placements of Straight Debt Using the Fama-French Calendar-time Portfolio Regressions}

For each month, we form a portfolio of all the sample firms that have offered private straight debt placement in the previous one-, three- and five-year and calculate both the equal- and value-weighted one-, three- and five-year long-run abnormal returns from 1989 to 2002. The monthly excess returns to the calendar time portfolios, $R_{p t}-R_{f t}$, are regressed on the Fama and French (1993) three-factor model in order to calculate the unadjusted intercept $\left(\alpha_{p}\right)$. The three factors, from Fama and French (1993), are the excess returns on the market portfolio $\left(R_{n t}-R_{f t}\right)$, the difference returns between the value-weighted portfolios of small stocks and big stocks $\left(S M B_{t}\right)$, and the difference returns between the value-weighted portfolios of high book-to-market stocks and low book-to-market stocks $\left(H M L_{L}\right)$. The ordinary and weighted least squares (OLS and WLS) time series regressions are estimated. Monthly returns in the WLS model are weighted by the square root of the number of sample firms contained in the monthly portfolio. The t-statistics of the intercept are reported.

$$
R_{p t}-R_{f t}=\alpha_{p}+\beta_{m}\left(R_{m t}-R_{f t}\right)+\beta_{s} S M B+\beta_{h} H M L_{t}+\varepsilon_{t}
$$

Panel A: One-year Fama-French Calendar-time Portfolio

\begin{tabular}{llccc}
\hline \multirow{2}{*}{ Calendar portfolio weighting } & $\begin{array}{l}\text { Model } \\
\text { estimated }\end{array}$ & $\alpha_{p}$ & t-statistic & Adj. $R^{2}$ \\
\hline EW & OLS & -0.2474 & -1.34 & 0.77 \\
& WLS & -0.2563 & -1.46 & 0.80 \\
VW & OLS & -0.2009 & -0.62 & 0.51 \\
& WLS & -0.2515 & -0.84 & 0.54 \\
\hline
\end{tabular}

Panel B: Three-year Fama-French Calendar-time Portfolio

\begin{tabular}{llccc}
\hline \multirow{2}{*}{ Calendar portfolio weighting } & Model \\
estimated & $\alpha_{p}$ & t-statistic & Adj. $R^{2}$ \\
\hline EW & OLS & -0.2014 & -1.38 & 0.84 \\
& WLS & -0.2297 & -1.60 & 0.85 \\
VW & OLS & 0.0141 & 0.07 & 0.74 \\
& WLS & -0.0296 & -0.15 & 0.75 \\
\hline
\end{tabular}

Panel C: Five-year Fama-French Calendar-time Portfolio

\begin{tabular}{llccc}
\hline \multirow{2}{*}{ Calendar portfolio weighting } & $\begin{array}{l}\text { Model } \\
\text { estimated }\end{array}$ & $\alpha_{p}$ & t-statistic & Adj. $R^{2}$ \\
\hline EW & OLS & -0.0951 & -0.68 & 0.86 \\
& WLS & -0.1100 & -0.80 & 0.86 \\
VW & OLS & -0.1189 & -0.77 & 0.82 \\
& WLS & -0.1168 & -0.78 & 0.82
\end{tabular}

$*, * *$ and $* * *$ significantly different from zero at the $10 \%, 5 \%$ and $1 \%$ level, respectively. 
Table 5 Long-run Abnormal Returns Following Private Placements of Convertible Debt Using the Fama-French Calendar-time Portfolio Regressions

For each month, we form a portfolio of all the sample firms that have offered private convertible debt placement in the previous one-, three- and five-year and calculate both the equal- and value-weighted one-, three- and five-year long-run abnormal returns from 1989 to 2002. The monthly excess returns to the calendar time portfolios, $R_{p t}-R_{f t}$, are regressed on the Fama and French (1993) three-factor model in order to calculate the unadjusted intercept $\left(\alpha_{p}\right)$. The three factors, from Fama and French (1993), are the excess returns on the market portfolio $\left(R_{n t}-R_{f t}\right)$, the difference returns between the value-weighted portfolios of small stocks and big stocks $\left(S M B_{t}\right)$, and the difference returns between the value-weighted portfolios of high book-to-market stocks and low book-to-market stocks $\left(H M L_{L}\right)$. The ordinary and weighted least squares (OLS and WLS) time series regressions are estimated. Monthly returns in the WLS model are weighted by the square root of the number of sample firms contained in the monthly portfolio. The t-statistics of the intercept are reported.

\begin{tabular}{|c|c|c|c|c|}
\hline \multicolumn{5}{|c|}{$\begin{array}{c}\quad R_{p t}-R_{f t}=\alpha_{p}+\beta_{m}\left(R_{m t}-R_{f t}\right)+\beta_{s} S M B+\beta_{h} H M L_{t}+\varepsilon_{t} \\
\text { Panel A: One-year Fama-French Calendar-time Portfolio }\end{array}$} \\
\hline Calendar portfolio weighting & $\begin{array}{l}\text { Model } \\
\text { estimated }\end{array}$ & $\alpha_{p}$ & t-statistic & Adj. $R^{2}$ \\
\hline$\overline{\mathrm{EW}}$ & $\begin{array}{l}\text { OLS } \\
\text { WLS }\end{array}$ & $\begin{array}{l}-0.6780 \\
-1.1509\end{array}$ & $\begin{array}{l}-1.06 \\
-1.92 *\end{array}$ & $\begin{array}{l}0.52 \\
0.57\end{array}$ \\
\hline VW & $\begin{array}{l}\text { OLS } \\
\text { WLS }\end{array}$ & $\begin{array}{r}0.0497 \\
-0.0347\end{array}$ & $\begin{array}{r}0.07 \\
-0.05\end{array}$ & $\begin{array}{l}0.33 \\
0.32\end{array}$ \\
\hline \multicolumn{5}{|c|}{ Panel B: Three-year Fama-French Calendar-time Portfolio } \\
\hline Calendar portfolio weighting & $\begin{array}{l}\text { Model } \\
\text { estimated }\end{array}$ & $\alpha_{p}$ & t-statistic & Adj. $R^{2}$ \\
\hline$\overline{\mathrm{EW}}$ & $\begin{array}{l}\text { OLS } \\
\text { WLS }\end{array}$ & $\begin{array}{l}-0.7656 \\
-0.9992\end{array}$ & $\begin{array}{l}-1.62 \\
-2.17 * *\end{array}$ & $\begin{array}{l}0.66 \\
0.68\end{array}$ \\
\hline VW & $\begin{array}{l}\text { OLS } \\
\text { WLS }\end{array}$ & $\begin{array}{l}-0.5698 \\
-0.7003\end{array}$ & $\begin{array}{l}-1.17 \\
-1.49\end{array}$ & $\begin{array}{l}0.57 \\
0.59\end{array}$ \\
\hline \multicolumn{5}{|c|}{ Panel C: Five-year Fama-French Calendar-time Portfolio } \\
\hline Calendar portfolio weighting & $\begin{array}{l}\text { Model } \\
\text { estimated }\end{array}$ & $\alpha_{p}$ & t-statistic & Adj. $R^{2}$ \\
\hline$\overline{\mathrm{EW}}$ & $\begin{array}{l}\text { OLS } \\
\text { WLS }\end{array}$ & $\begin{array}{l}-0.4507 \\
-0.6696\end{array}$ & $\begin{array}{l}-1.06 \\
-1.66^{*}\end{array}$ & $\begin{array}{l}0.69 \\
0.72\end{array}$ \\
\hline VW & $\begin{array}{l}\text { OLS } \\
\text { WLS }\end{array}$ & $\begin{array}{l}-0.3343 \\
-0.4926\end{array}$ & $\begin{array}{l}-0.77 \\
-1.21\end{array}$ & $\begin{array}{l}0.61 \\
0.65\end{array}$ \\
\hline
\end{tabular}

$*, * *$, and $* * *$ Test statistic is significant at the $10 \%, 5 \%$, and $1 \%$ level, respectively. 


\section{Table 6 Long-run Abnormal Returns Following Private Placements of Straight Debt Using the Carhart Four-factor Model}

For each month, we form a portfolio of all sample firms that have offered the private straight debt placement in the previous one-, three- and five-year and calculate both the equal- and value-weighted one-, three- and five-year long-run abnormal returns from 1989 to 2002. The monthly excess returns to the calendar time portfolios, $R_{p t}-R_{f t}$, are regressed on the Carhart (1997) four-factor model in order to calculate the unadjusted intercept $\left(\alpha_{p}\right)$. The excess returns on the market portfolio $\left(R_{n t}-R_{j}\right)$, the difference returns between value-weighted portfolios of small stocks and big stocks $\left(S M B_{t}\right)$, and the difference returns between value-weighted portfolios of high book-to-market stocks and low book-to-market stocks $(H M L)$ are obtained from Fama and French. The $P R 1 Y R$ is defined as the difference between an equally-weighted portfolio return of stocks with the highest 30 percent returns and an equal- weighted portfolio return of stocks with the lowest 30 percent returns in months $t-12$ to $t-2$. The ordinary and weighted least squares (OLS and WLS) time series regressions are estimated. Monthly returns in the WLS model are weighted by the square root of the number of sample firms contained in the monthly portfolio. The $t$-statistics of the intercept are reported, and $\mathrm{N}$ is the number of monthly observations.

\begin{tabular}{|c|c|c|c|c|}
\hline \multicolumn{5}{|c|}{$\begin{array}{c}R_{p t}-R_{f t}=\alpha_{p}+\beta_{m}\left(R_{m t}-R_{f t}\right)+\beta_{s} S M B_{t}+\beta_{h} H M L_{t}+P R \mid Y R+\varepsilon_{t} \\
\text { Panel A: One-year Carhart four-factor model }\end{array}$} \\
\hline Calendar portfolio weighting & $\begin{array}{l}\text { Model } \\
\text { estimated }\end{array}$ & $\alpha_{p}$ & t-statistic & $\operatorname{Adj} . R^{2}$ \\
\hline EW & $\begin{array}{l}\text { OLS } \\
\text { WLS }\end{array}$ & $\begin{array}{l}-0.2859 \\
-0.2769\end{array}$ & $\begin{array}{l}-1.51 \\
-1.54\end{array}$ & $\begin{array}{l}0.76 \\
0.78\end{array}$ \\
\hline VW & $\begin{array}{l}\text { OLS } \\
\text { WLS }\end{array}$ & $\begin{array}{l}-0.2999 \\
-0.3163\end{array}$ & $\begin{array}{l}-0.96 \\
-1.09\end{array}$ & $\begin{array}{l}0.50 \\
0.54\end{array}$ \\
\hline \multicolumn{5}{|c|}{ Panel B: Three-year Carhart four-factor model } \\
\hline Calendar portfolio weighting & $\begin{array}{l}\text { Model } \\
\text { estimated }\end{array}$ & $\alpha_{p}$ & t-statistic & $\operatorname{Adj} . R^{2}$ \\
\hline EW & $\begin{array}{l}\text { OLS } \\
\text { WLS }\end{array}$ & $\begin{array}{l}-0.2779 \\
-0.2840\end{array}$ & $\begin{array}{l}-1.84^{*} \\
-1.93^{*}\end{array}$ & $\begin{array}{l}0.84 \\
0.85\end{array}$ \\
\hline VW & $\begin{array}{l}\text { OLS } \\
\text { WLS }\end{array}$ & $\begin{array}{l}-0.0992 \\
-0.1100\end{array}$ & $\begin{array}{l}-0.47 \\
-0.55\end{array}$ & $\begin{array}{l}0.73 \\
0.75\end{array}$ \\
\hline \multicolumn{5}{|c|}{ Panel C: Five-year Carhart four-factor model } \\
\hline Calendar portfolio weighting & $\begin{array}{l}\text { Model } \\
\text { estimated }\end{array}$ & $\alpha_{p}$ & t-statistic & $\operatorname{Adj} . R^{2}$ \\
\hline EW & $\begin{array}{l}\text { OLS } \\
\text { WLS }\end{array}$ & $\begin{array}{l}-0.1411 \\
-0.1471\end{array}$ & $\begin{array}{l}-0.97 \\
-1.04\end{array}$ & $\begin{array}{l}0.85 \\
0.85\end{array}$ \\
\hline VW & $\begin{array}{l}\text { OLS } \\
\text { WLS }\end{array}$ & $\begin{array}{l}-0.1882 \\
-0.1745\end{array}$ & $\begin{array}{l}-1.19 \\
-1.14\end{array}$ & $\begin{array}{l}0.82 \\
0.82\end{array}$ \\
\hline
\end{tabular}

*, **, and *** Test statistic is significant at the $10 \%, 5 \%$, and $1 \%$ level, respectively. 
Table 7 Long-run Abnormal Returns Following Private Placements of Convertible Debt Using the Carhart Four-factor Model

For each month, we form a portfolio of all sample firms that have offered the private convertible debt placement in the previous one-, three- and five-year and calculate both the equal- and value-weighted one-, three- and five-year long-run abnormal returns from 1989 to 2002. The monthly excess returns to the calendar time portfolios, $R_{p t}-R_{f t}$, are regressed on the Carhart (1997) four-factor model in order to calculate the unadjusted intercept $\left(\alpha_{p}\right)$. The excess returns on the market portfolio $\left(R_{m t}-R_{j i}\right)$, the difference returns between value-weighted portfolios of small stocks and big stocks $\left(S M B_{t}\right)$, and the difference returns between value-weighted portfolios of high book-to-market stocks and low book-to-market stocks $(H M L)$ are obtained from Fama and French. The $P R 1 Y R$ is defined as the difference between an equally-weighted portfolio return of stocks with the highest 30 percent returns and an equal- weighted portfolio return of stocks with the lowest 30 percent returns in months $t-12$ to $t-2$. The ordinary and weighted least squares (OLS and WLS) time series regressions are estimated. Monthly returns in the WLS model are weighted by the square root of the number of sample firms contained in the monthly portfolio. The $t$-statistics of the intercept are reported, and $\mathrm{N}$ is the number of monthly observations.

\begin{tabular}{|c|c|c|c|c|}
\hline \multicolumn{5}{|c|}{$\begin{array}{c}R_{p t}-R_{f t}=\alpha_{p}+\beta_{m}\left(R_{m t}-R_{f t}\right)+\beta_{s} S M B_{t}+\beta_{h} H M L_{t}+P R I Y R+\varepsilon_{t} \\
\text { Panel A: One-year Carhart four-factor model }\end{array}$} \\
\hline Calendar portfolio weighting & $\begin{array}{l}\text { Model } \\
\text { estimated }\end{array}$ & $\alpha_{p}$ & t-statistic & Adj. $R^{2}$ \\
\hline EW & $\begin{array}{l}\text { OLS } \\
\text { WLS }\end{array}$ & $\begin{array}{l}-0.5449 \\
-0.8724\end{array}$ & $\begin{array}{l}-0.84 \\
-1.41\end{array}$ & $\begin{array}{l}0.53 \\
0.57\end{array}$ \\
\hline VW & $\begin{array}{l}\text { OLS } \\
\text { WLS }\end{array}$ & $\begin{array}{l}-0.0788 \\
-0.2785\end{array}$ & $\begin{array}{l}-0.11 \\
-0.40\end{array}$ & $\begin{array}{l}0.35 \\
0.35\end{array}$ \\
\hline \multicolumn{5}{|c|}{$\begin{array}{cc}\text { Panel B: Three-year Carhart four-factor model } \\
\end{array}$} \\
\hline Calendar portfolio weighting & $\begin{array}{l}\text { Model } \\
\text { estimated }\end{array}$ & $\alpha_{p}$ & t-statistic & Adj. $R^{2}$ \\
\hline EW & $\begin{array}{l}\text { OLS } \\
\text { WLS }\end{array}$ & $\begin{array}{l}-0.6917 \\
-0.8814\end{array}$ & $\begin{array}{l}-1.47 \\
-1.96^{*}\end{array}$ & $\begin{array}{l}0.66 \\
0.69\end{array}$ \\
\hline VW & $\begin{array}{l}\text { OLS } \\
\text { WLS }\end{array}$ & $\begin{array}{l}-0.6191 \\
-0.7976\end{array}$ & $\begin{array}{l}-1.24 \\
-1.64\end{array}$ & $\begin{array}{l}0.57 \\
0.58\end{array}$ \\
\hline & Panel C: $\mathbf{F}$ & hart four & odel & \\
\hline Calendar portfolio weighting & $\begin{array}{l}\text { Model } \\
\text { estimated }\end{array}$ & $\alpha_{p}$ & t-statistic & Adj. $R^{2}$ \\
\hline$\overline{\mathrm{EW}}$ & $\begin{array}{l}\text { OLS } \\
\text { WLS }\end{array}$ & $\begin{array}{l}-0.3795 \\
-0.5572\end{array}$ & $\begin{array}{l}-0.90 \\
-1.44\end{array}$ & $\begin{array}{l}0.69 \\
0.74\end{array}$ \\
\hline VW & $\begin{array}{l}\text { OLS } \\
\text { WLS }\end{array}$ & $\begin{array}{l}-0.3462 \\
-0.5072\end{array}$ & $\begin{array}{l}-0.78 \\
-1.21\end{array}$ & $\begin{array}{l}0.61 \\
0.63\end{array}$ \\
\hline
\end{tabular}

*,**, and *** Test statistic is significant at the $10 \%, 5 \%$, and $1 \%$ level, respectively. 


\section{Table 8 Operating Performance before and after Private Placements of Straight Debt}

This table presents the median operating performance of the sample firm and the industry-adjusted operating performance of the sample firm for the three fiscal years before and three fiscal years after the offering of private straight debt placements. Year 0 is the year of the offering while the other year represents the fiscal year relative to the year of the offering. $\quad \mathrm{N}$ is the number of observations with available COMPUSTAT data. The operating performance measures, the IBER/Assets, the IBER/Equity and the IBER/Sales are defined as the operating income before extraordinary items scaled by total assets, total book value of equity and sales. $\mathrm{CE}+\mathrm{RD} /$ Assets indicate capital expenditures plus research and development expenditures deflated by total assets. If $\mathrm{CE}$ or $\mathrm{RD}$ is missing from COMPUSTAT, then their values are set equal to $0 . \mathrm{M} / \mathrm{B}$, market-to-book, represents the number of outstanding shares multiplied by fiscal year-end price divided by the book value of equity. TIE, times-interest-earned ratio, a measure of operating income before interest expense and taxes over interest expenses. Sample firms are firms that offered private straight debt placements from 1989 to 2002. Significance tests are based on the Wilcoxon signed rank tests.

\begin{tabular}{|c|c|c|c|c|c|c|c|}
\hline \multicolumn{8}{|c|}{ Panel A: Results on the median and industry-adjusted median levels of operating performance } \\
\hline Year & -3 & -2 & -1 & 0 & 1 & 2 & 3 \\
\hline \multicolumn{8}{|l|}{ IBER/Sales $(\%)$ : } \\
\hline Sample firm & $0.0460 * * *$ & $0.0458 * * *$ & $0.0474 * * *$ & $0.0417 * * *$ & $0.0350 * * *$ & $0.0360 * * *$ & $0.0354 * * *$ \\
\hline Industry-adjusted & $0.0150 * * *$ & $0.0165 * * *$ & $0.0174 * * *$ & $0.0128 * * *$ & $0.0083 * * *$ & $0.0109 * * *$ & $0.0053 * *$ \\
\hline $\mathrm{N}$ & 695 & 764 & 811 & 778 & 727 & 670 & 605 \\
\hline \multicolumn{8}{|l|}{ IBER/Assets (\%): } \\
\hline Sample firm & $0.0472 * * *$ & $0.0481 * * *$ & $0.0475 * * *$ & $0.0387 * * *$ & $0.0348 * * *$ & $0.0340 * * *$ & $0.0349 * * *$ \\
\hline Industry-adjusted & $0.0168 * * *$ & $0.0136 * * *$ & $0.0151 * * *$ & $0.0101 * * *$ & $0.0079 * * *$ & $0.0082 * * *$ & 0.0047 \\
\hline $\mathrm{N}$ & 695 & 764 & 811 & 778 & 727 & 670 & 605 \\
\hline \multicolumn{8}{|l|}{ IBER/Equity (\%): } \\
\hline Sample firm & $0.1225 * * *$ & $0.1216 * * *$ & $0.1187 * * *$ & $0.1085 * * *$ & $0.1030 * * *$ & $0.1055^{* * *}$ & $0.1089 * * *$ \\
\hline Industry-adjusted & $0.0328 * * *$ & $0.0210 * * *$ & $0.0223 * * *$ & $0.0195 * * *$ & $0.0109 * *$ & $0.0130 * * *$ & $0.0146 * * *$ \\
\hline $\mathrm{N}$ & 695 & 764 & 811 & 778 & 727 & 670 & 605 \\
\hline \multicolumn{8}{|l|}{ CE+RD/Assets (\%): } \\
\hline Sample firm & $0.0828 * * *$ & $0.0779 * * *$ & $0.0807 * * *$ & $0.0762 * * *$ & $0.0742 * * *$ & $0.0700 * * *$ & $0.0690 * * *$ \\
\hline Industry-adjusted & $0.0062 * * *$ & $0.0064 * * *$ & $0.0077 * * *$ & $0.0050 * * *$ & $0.0032 * * *$ & $0.0023 * * *$ & $0.0012 * * *$ \\
\hline $\mathrm{N}$ & 695 & 764 & 811 & 778 & 727 & 670 & 605 \\
\hline \multicolumn{8}{|l|}{ M/B (\%): } \\
\hline Sample firm & $1.7757 * * *$ & $1.7659 * * *$ & $1.7750 * * *$ & $1.7236 * * *$ & $1.6355 * * *$ & $1.6906 * * *$ & $1.7925 * * *$ \\
\hline Industry-adjusted & $0.1396 * * *$ & $0.1745 * * *$ & $0.2118 * * *$ & $0.1179 * * *$ & $0.0850 * * *$ & $0.0832 * * *$ & $0.0502 * * *$ \\
\hline $\mathrm{N}$ & 695 & 764 & 811 & 778 & 727 & 670 & 605 \\
\hline \multicolumn{8}{|l|}{ TIE (\%): } \\
\hline Sample firm & $3.9523 * * *$ & $3.9087 * * *$ & $3.8351 * * *$ & $3.1927 * * *$ & $2.8990 * * *$ & $2.9890 * * *$ & $3.4092 * * *$ \\
\hline Industry-adjusted & $1.2309 * * *$ & $1.0391 * * *$ & $1.1576 * * *$ & $0.7664 * * *$ & $0.4975 * * *$ & $0.5820 * * *$ & $0.5250 * * *$ \\
\hline $\mathrm{N}$ & 695 & 764 & 811 & 778 & 727 & 670 & 605 \\
\hline
\end{tabular}


Table 8 (continued)

\begin{tabular}{|c|c|c|c|c|c|c|}
\hline \multicolumn{7}{|c|}{ Panel B: Results on the year-by-year median change in operating performance } \\
\hline Year & $(-3,-2)$ & $(-2,-1)$ & $(-1,0)$ & $(0,1)$ & $(1,2)$ & $(2,3)$ \\
\hline \multicolumn{7}{|l|}{ Median change in } \\
\hline Sample firm & 0.0003 & 0.0008 & $-0.0032 * * *$ & $-0.0016 * * *$ & 0.0010 & 0.0004 \\
\hline Industry-adjusted & 0.0006 & 0.0020 & $-0.0023 * * *$ & $-0.0026 * * *$ & 0.0024 & $0.0026 * *$ \\
\hline $\mathrm{N}$ & 691 & 760 & 768 & 724 & 669 & 605 \\
\hline \multicolumn{7}{|l|}{ Median change in } \\
\hline Sample firm & 0.0006 & -0.0002 & $-0.0049 * * *$ & $-0.0020 * * *$ & 0.0002 & 0.0003 \\
\hline Industry-adjusted & 0.0017 & 0.0004 & $-0.0034 * * *$ & $-0.0031 * * *$ & 0.0010 & $-0.0015^{*}$ \\
\hline $\mathrm{N}$ & 691 & 760 & 768 & 724 & 669 & 605 \\
\hline \multicolumn{7}{|l|}{ Median change in } \\
\hline Sample firm & 0.0007 & 0.0001 & $-0.0079 * * *$ & $-0.0071 * * *$ & -0.0029 & -0.0008 \\
\hline Industry-adjusted & $-0.0056 * * *$ & 0.0030 & $-0.0042 * *$ & $-0.0071 * * *$ & -0.0007 & -0.0038 \\
\hline $\mathrm{N}$ & 691 & 760 & 768 & 724 & 669 & 605 \\
\hline \multicolumn{7}{|l|}{ Median change in } \\
\hline Sample firm & 0.0007 & $0.0017 * * *$ & $-0.0010 * * *$ & $-0.0021 * * *$ & $-0.0021 * * *$ & $-0.0017 * *$ \\
\hline Industry-adjusted & 0.0006 & $0.0013 * *$ & $-0.0011 * *$ & $-0.0010^{*}$ & $-0.0012 * *$ & 0.0009 \\
\hline $\mathrm{N}$ & 691 & 760 & 768 & 724 & 669 & 605 \\
\hline \multicolumn{7}{|c|}{ Median change in M/B (\%): } \\
\hline Sample firm & -0.0188 & 0.0056 & $-0.0321 * *$ & $-0.0442 *$ & $0.0750 * * *$ & 0.0210 \\
\hline Industry-adjusted & -0.0401 & 0.0169 & $-0.0219 * *$ & -0.0153 & -0.0025 & 0.0557 \\
\hline $\mathrm{N}$ & 691 & 760 & 768 & 724 & 669 & 605 \\
\hline
\end{tabular}


Table 8 (continued)

\begin{tabular}{|c|c|c|c|c|}
\hline \multicolumn{5}{|c|}{ Panel C: Results on the median change in operating performance from year $\mathbf{- 1}$} \\
\hline Year & $(-1,0)$ & $(-1,1)$ & $(-1,2)$ & $(-1,3)$ \\
\hline \multicolumn{5}{|c|}{ Median change in IBER/Sales (\%): } \\
\hline Sample firm & $-0.0032 * * *$ & $-0.0080 * * *$ & $-0.0072 * * *$ & $-0.0079 * * *$ \\
\hline Industry-adjusted & $-0.0022 * * *$ & $-0.0069 * * *$ & $-0.0061 * * *$ & $-0.0086^{* * *}$ \\
\hline $\mathrm{N}$ & 778 & 727 & 670 & 605 \\
\hline \multicolumn{5}{|c|}{ Median change in IBER/Assets $(\%)$ : } \\
\hline Sample firm & $-0.0048 * * *$ & $-0.0093 * * *$ & $-0.0104 * * *$ & $-0.0121 * * *$ \\
\hline Industry-adjusted & $-0.0033 * * *$ & $-0.0088 * * *$ & $-0.0068 * * *$ & $-0.0104 * * *$ \\
\hline $\mathrm{N}$ & 778 & 727 & 670 & 605 \\
\hline \multicolumn{5}{|c|}{ Median change in IBER/Equity (\%): } \\
\hline Sample firm & $-0.0077 * * *$ & $-0.0185^{* * *}$ & $-0.0208 * * *$ & $-0.0215^{* * *}$ \\
\hline Industry-adjusted & $-0.0035^{*}$ & $-0.0172 * * *$ & $-0.0127 * * *$ & $-0.0115^{* * *}$ \\
\hline $\mathrm{N}$ & 778 & 727 & 670 & 605 \\
\hline \multicolumn{5}{|c|}{ Median change in $\mathrm{CE}+\mathrm{RD} /$ Assets $(\%)$ : } \\
\hline Sample firm & $-0.0010 * * *$ & $-0.0044 * * *$ & $-0.0074 * * *$ & $-0.0111 * * *$ \\
\hline Industry-adjusted & $-0.0011 *$ & $-0.0027 * * *$ & $-0.0058 * * *$ & $-0.0083 * * *$ \\
\hline $\mathrm{N}$ & 778 & 727 & 670 & 605 \\
\hline \multicolumn{5}{|c|}{ Median change in M/B (\%): } \\
\hline Sample firm & $-0.0285^{*}$ & $-0.0860 * * *$ & -0.0240 & 0.0477 \\
\hline Industry-adjusted & $-0.0219 * *$ & $-0.0535^{* *}$ & $-0.1220 * * *$ & $-0.0978 *$ \\
\hline $\mathrm{N}$ & 778 & 727 & 670 & 605 \\
\hline
\end{tabular}

*, **, and *** Test statistic is significant at the $10 \%, 5 \%$, and $1 \%$ level, respectively. 
Table 9 Operating Performance before and after Private Placements of Convertible Debt

This table presents the median operating performance of the sample firm and the industry-adjusted operating performance of the sample firm for the three fiscal years before and three fiscal years after the offer of private convertible debt placements. All the sample firms were reported from the Securities Data Company's (SDC) online databases over the period from January 1989 through December 2002.Year 0 is the year of the offer while the other year represents the fiscal year relative to the year of the offer. $\mathrm{N}$ is the number of observations with available COMPUSTAT data. The operating performance measures, the IBER/Assets, the IBER/Equity and the IBER/Sales are defined as the operating income before extraordinary items scaled by total assets, total book value of equity and sales. $\mathrm{CE}+\mathrm{RD} / \mathrm{Assets}$ indicate capital expenditures plus research and development expenditures deflated by total assets. If $\mathrm{CE}$ or $\mathrm{RD}$ is missing from COMPUSTAT, then their values are set equal to $0 . \mathrm{M} / \mathrm{B}$, market-to-book, represents the number of outstanding shares multiplied by fiscal year-end price divided by the book value of equity. TIE, times-interest-earned ratio, a measure of operating income before interest expense and taxes over interest expenses. Sample firms are firms that offered private convertible debt placements from 1989 to 2002. Significance tests are based on the Wilcoxon signed rank tests.

\begin{tabular}{|c|c|c|c|c|c|c|c|}
\hline \multicolumn{8}{|c|}{ Panel A: Results on the median and industry-adjusted median levels of operating performance } \\
\hline Year & -3 & -2 & -1 & 0 & 1 & 2 & 3 \\
\hline \multicolumn{8}{|l|}{ IBER/Sales $(\%)$ : } \\
\hline Sample firm & 0.0272 & $0.0175^{*}$ & $0.0025 * * *$ & $0.0082 * *$ & 0.0105 & 0.0279 & 0.0237 \\
\hline Industry-adjusted & 0.0125 & $-0.0133 * *$ & $-0.0179 * * *$ & $-0.0158 * * *$ & -0.0103 & -0.0009 & -0.0170 \\
\hline $\mathrm{N}$ & 106 & 125 & 143 & 123 & 89 & 69 & 58 \\
\hline \multicolumn{8}{|l|}{ IBER/Assets (\%): } \\
\hline Sample firm & 0.0236 & 0.0147 & $0.0013 * * *$ & $0.0041 *$ & 0.0094 & 0.0247 & 0.0112 \\
\hline Industry-adjusted & 0.0096 & $-0.0060 * *$ & $-0.0147 * * *$ & $-0.0112 * *$ & $-0.0058 *$ & -0.0005 & $-0.0046^{* *}$ \\
\hline $\mathrm{N}$ & 106 & 125 & 143 & 123 & 89 & 69 & 58 \\
\hline \multicolumn{8}{|l|}{ IBER/Equity (\%): } \\
\hline Sample firm & $0.0844 *$ & 0.0489 & $0.0035 * * *$ & 0.0572 & 0.0631 & 0.0755 & 0.0629 \\
\hline Industry-adjusted & 0.0052 & $-0.0269 * * *$ & $-0.0607 * * *$ & -0.0036 & 0.0123 & 0.0034 & 0.0034 \\
\hline $\mathrm{N}$ & 106 & 125 & 143 & 123 & 89 & 69 & 58 \\
\hline \multicolumn{8}{|l|}{$\mathrm{CE}+\mathrm{RD} /$ Assets $(\%)$ : } \\
\hline Sample firm & $0.0902 * * *$ & $0.1053 * * *$ & $0.1159 * * *$ & $0.1087 * * *$ & $0.1030 * * *$ & $0.0951 * * *$ & $0.1036^{* * * *}$ \\
\hline Industry-adjusted & -0.0008 & $0.0078 * * *$ & $0.0135 * * *$ & $0.0008 * *$ & $0.0038 * * *$ & $0.0087 * *$ & $0.0010^{*}$ \\
\hline $\mathrm{N}$ & 106 & 125 & 143 & 123 & 89 & 69 & 58 \\
\hline \multicolumn{8}{|l|}{ M/B (\%): } \\
\hline Sample firm & $2.3474 * * *$ & $2.2172 * * *$ & $2.3073 * * *$ & $2.3754 * * *$ & $2.0303 * * *$ & $1.8819 * * *$ & $1.9878 * * *$ \\
\hline Industry-adjusted & $0.7554 * * *$ & $0.4950 * * *$ & $0.5434 * * *$ & $0.4356^{* * *}$ & $0.1903^{*}$ & 0.0524 & 0.2389 \\
\hline $\mathrm{N}$ & 106 & 125 & 143 & 123 & 89 & 69 & 58 \\
\hline \multicolumn{8}{|l|}{ TIE (\%): } \\
\hline Sample firm & 1.7245 & 1.4296 & 0.6050 & 1.1254 & $1.6184 * * *$ & $2.0857 * *$ & $1.9484^{*}$ \\
\hline Industry-adjusted & -0.1337 & $-0.3394 *$ & -0.4859 & -0.5814 & -0.0395 & -0.4300 & 0.1310 \\
\hline $\mathrm{N}$ & 106 & 125 & 143 & 123 & 89 & 69 & 58 \\
\hline
\end{tabular}


Table 9 (continued)

\begin{tabular}{|c|c|c|c|c|c|c|}
\hline \multicolumn{7}{|c|}{ Panel B: Results on the year-by-year median change in operating performance } \\
\hline Year & $(-3,-2)$ & $(-2,-1)$ & $(-1,0)$ & $(0,1)$ & $(1,2)$ & $(2,3)$ \\
\hline \multicolumn{7}{|l|}{ Median change in } \\
\hline Sample firm & $-0.0084 * *$ & -0.0025 & 0.0027 & -0.0002 & -0.0018 & -0.0067 \\
\hline Industry-adjusted & -0.0073 & -0.0012 & -0.0023 & 0.0051 & -0.0015 & -0.0081 \\
\hline $\mathrm{N}$ & 100 & 122 & 115 & 88 & 69 & 58 \\
\hline \multicolumn{7}{|l|}{ Median change in } \\
\hline Sample firm & -0.0047 & $-0.0066 * *$ & -0.0048 & -0.0023 & -0.0006 & -0.0005 \\
\hline Industry-adjusted & 0.0001 & $-0.0117 *$ & -0.0052 & -0.0009 & 0.0006 & -0.0003 \\
\hline $\mathrm{N}$ & 100 & 122 & 115 & 88 & 69 & 58 \\
\hline \multicolumn{7}{|l|}{ Median change in } \\
\hline Sample firm & $-0.0264 * *$ & $-0.0294 * * *$ & 0.0103 & -0.0116 & -0.0081 & -0.0142 \\
\hline Industry-adjusted & $-0.0407 * * *$ & $-0.0497 * * *$ & 0.0127 & -0.0098 & -0.0075 & -0.0262 \\
\hline $\mathrm{N}$ & 100 & 122 & 115 & 88 & 69 & 58 \\
\hline \multicolumn{7}{|l|}{ Median change in } \\
\hline Sample firm & $0.0065^{*}$ & -0.0007 & -0.0003 & 0.0041 & -0.0019 & -0.0011 \\
\hline Industry-adjusted & 0.0012 & -0.0041 & -0.0009 & 0.0036 & -0.0010 & -0.0009 \\
\hline $\mathrm{N}$ & 100 & 122 & 115 & 88 & 69 & 58 \\
\hline \multicolumn{7}{|c|}{ Median change in M/B (\%): } \\
\hline Sample firm & $-0.3125^{* * *}$ & 0.1921 & 0.0991 & $-0.3351 * * *$ & -0.0464 & 0.0036 \\
\hline Industry-adjusted & $-0.2988 * * *$ & 0.1683 & 0.1257 & $-0.4251 * * *$ & -0.1990 & 0.0165 \\
\hline $\mathrm{N}$ & 100 & 122 & 115 & 88 & 69 & 58 \\
\hline
\end{tabular}


Table 9 (continued)

\begin{tabular}{|c|c|c|c|c|}
\hline \multicolumn{5}{|c|}{ Panel C: Results on the median change in operating performance from year $\mathbf{- 1}$} \\
\hline Year & $(-1,0)$ & $(-1,1)$ & $(-1,2)$ & $(-1,3)$ \\
\hline \multicolumn{5}{|c|}{ Median change in IBER/Sales (\%): } \\
\hline Sample firm & 0.0022 & 0.0022 & 0.0026 & -0.0164 \\
\hline Industry-adjusted & -0.0027 & -0.0067 & -0.0085 & -0.0144 \\
\hline $\mathrm{N}$ & 123 & 89 & 69 & 58 \\
\hline \multicolumn{5}{|c|}{ Median change in IBER/Assets (\%): } \\
\hline Sample firm & -0.0048 & -0.0033 & -0.0028 & -0.0032 \\
\hline Industry-adjusted & -0.0056 & -0.0056 & -0.0044 & 0.0006 \\
\hline $\mathrm{N}$ & 123 & 89 & 69 & 58 \\
\hline \multicolumn{5}{|c|}{ Median change in IBER/Equity (\%): } \\
\hline Sample firm & 0.0125 & 0.0045 & 0.0070 & 0.0128 \\
\hline Industry-adjusted & 0.0164 & 0.0056 & -0.0041 & 0.0101 \\
\hline $\mathrm{N}$ & 123 & 89 & 69 & 58 \\
\hline \multicolumn{5}{|c|}{ Median change in $\mathrm{CE}+\mathrm{RD} /$ Assets $(\%)$ : } \\
\hline Sample firm & -0.0001 & -0.0027 & -0.0004 & -0.0023 \\
\hline Industry-adjusted & -0.0009 & -0.0041 & -0.0052 & -0.0049 \\
\hline $\mathrm{N}$ & 123 & 89 & 69 & 58 \\
\hline \multicolumn{5}{|c|}{ Median change in $\mathrm{M} / \mathrm{B}(\%)$ : } \\
\hline Sample firm & 0.0770 & $-0.1803 * *$ & $-0.2525^{*}$ & -0.3251 \\
\hline Industry-adjusted & 0.1241 & $-0.4130 *$ & $-0.5731 * *$ & $-0.4480^{*}$ \\
\hline $\mathrm{N}$ & 123 & 89 & 69 & 58 \\
\hline
\end{tabular}

